Cahiers $d u$ MONDE RUSSE

\section{Cahiers du monde russe}

Russie - Empire russe - Union soviétique et États indépendants

$51 / 4 \mid 2010$

Sciences humaines et sociales en Russie à l'Âge d'argent

\title{
Moshe Gammer, ed., Islam and Sufism in Daghestan
}

\section{Paolo Sartori}

\section{(2) OpenEdition}

1 Journals

\section{Electronic version}

URL: https://journals.openedition.org/monderusse/7438

DOI: 10.4000/monderusse. 7438

ISSN: $1777-5388$

\section{Publisher}

Éditions de l'EHESS

\section{Printed version}

Date of publication: 25 November 2010

Number of pages: 803-805

ISBN: 978-2-7132-2316-7

ISSN: $1252-6576$

\section{Electronic reference}

Paolo Sartori, "Moshe Gammer, ed., Islam and Sufism in Daghestan", Cahiers du monde russe [Online], 51/4 | 2010, Online since 09 December 2011, connection on 04 September 2022. URL: http:// journals.openedition.org/monderusse/7438 ; DOl: https://doi.org/10.4000/monderusse.7438

This text was automatically generated on 4 September 2022.

All rights reserved 


\title{
Moshe Gammer, ed., Islam and Sufism in Daghestan
}

\author{
Paolo Sartori
}

\section{REFERENCES}

Moshe GAMMER, ed., Islam and Sufism in Daghestan. Sastamala : Finnish Academy of Science and Letters, 2009, 192 p.

1 This volume consists of ten essays concerning the history of Islamic institutions and Muslim culture in a region which coincides with present-day Daghestan. The contributions vary substantially in scope and approach and cover an ample time span, from the Middle Ages to the post-Soviet era.

In section 1 ("Places of Worship"), Amri Shikhsaidov provides a cursory historical survey of the first mosques of Daghestan, describing the establishment of the first places of Islamic worship in the city of Derbent. In the second essay of the section, Murtazali Hajiev reports on a number of findings related to the discovery of the Bāb alQiyāma (the Gate of the Day of Judgment), a major pilgrimage site (ziyāra) situated near Derbent. An inscription on the gate allows it to be dated to the year 1412. The essay includes extensive descriptions of the site's architectural features.

3 Section 2 ("Religious Leaders") brings together four short essays which introduce the reader to the biographies and the works of a number of Muslim divines and literati from Daghestan. These essays are packed with informative detail but lack original analysis. Their authors appear to have been almost exclusively concerned with offering lists of personal names, titles of religious scholarship, biographical data, etc., and the reader will find little analytical insights. In this respect, the essay authored by Makhach Musayev and Diana Alkhasova is more satisfactory, for it attempts to situate the intellectual trajectories of several Daghestani Muslim scholars within the transnational circles of Islamic education. The essay fails to achieve its goal, however, as it does not attempt to assemble a prosopography of the Daghestani 'ulamā'. 
The most solid part of the volume is represented by section 3 ("Law Matters"), with two essays authored by Michael Kemper and Vladimir Bobrovnikov, respectively. In "Ghazi Muhammad's Treatise Against Daghestani Customary Law," Kemper interprets the rise of the jihād movement in 1830, which "[kept] the Russian military busy in Daghestan until 1859, and in other parts of the Caucasus until the early 1860s," as the radicalization of a preexisting local discourse on Islamic law, which advocated the replacement of Daghestani customary law by shari $a$. To support this argument, Kemper offers a translation of Bahir al-burhān li-irtidād 'urafā' Daghistan, a treatise against customary law compiled by Ghāzī Muhammad some time before 1826/7, in which it is stated that "Muslims who follow 'ādat instead of sharía are unbelievers." Besides providing an English rendering of the text (an enterprise per se laudable since there are no Russian translation of the manuscript), the essay admirably situates the production of Ghāzī Muhammad's text within the broader historical context of the region and the local Islamic discourse. In this respect, Kemper warns the reader that the Bahir al-burhān "does not mark the beginning of the jihad against the Muslims who allegedly became apostate" and thus introduces an element of cautiousness to scholarly attempts to interpret the treatise as an ideological reference in relation to the war waged against the Russians. Equally important are Kemper's evaluations with regard to Ghazi Muhammad's silence on Sufi topoi. A cursory analysis of the sources he employed - mainly authored by local Shafi'i scholars from the late eighteenth to early nineteenth centuries - leads Kemper to argue that the jihād movement of Ghazi Muhammad was fully embedded in a local discourse on the role of sharita vis a vis 'âdat, apparently uninfluenced by the Naqshbandiyya and Khalidiyya Sufi brotherhoods.

5 Vladimir Bobrovnikov's contribution is a study of the establishment of sharita courts in Daghestan during the early Soviet period. This essay draws largely on his previous research and to some extent complements his groundbreaking work, Musul'mane severnogo Kavkaza : obychai, pravo, nasilie (M. : Vost. Lit., 2002). This essay is not a study in legal history, but rather an attempt to explore the political atmosphere and the intellectual premises that allowed shari $a$ to officially exist in Daghestan until 1927. The most interesting aspect of the essay is Bobrovnikov's portrayal of the Bolsheviks' rise to power as the result of an alliance with Sufi shaykhs who headed local institutions such as the revkom. He points out that the understaffed, poorly financed, badly organized Soviet administration was virtually obliged to opt for indirect rule, a pattern which we also see at work in Central Asia during the same period. The essay is enriched by the translation into English of seven documents, which range from the statute of sharita courts in the Autonomous Soviet Republic of Daghestan (1922) to certificates of land purchase, and marriage contracts notarized by qadis between 1901 and 1918. More extensive commentary on these documents would be desirable, to give the reader a clearer picture of the historical context in which they were produced, their value, and the criteria according to which the author selected them.

6 The last section (“The Post-Soviet Situation") brings together two enjoyable essays that focus on topics of great interest: Sufi culture and Islamic education in present-day Daghestan. First, Shamil Shikhaliev provides an interesting account of the ritual practices that appear to distinguish the two branches of the Naqshbandiyya brotherhood (the Khalidiyya and the Mahmudiyya). The essay is a careful, detailed portrait of the practices that a student affiliated to one or the other brotherhood has to master in order to ascend the Sufi path. It is based on field material that the author collected between 
2002 and 2003 and has an ambitious goal : "to demystify it [Sufism P.S.] from misleading approaches and from concepts dating back to the Cold War period." Given the limited scope of the study, it could be argued that the author has only partially succeeded in his undertaking; however, it should be pointed out that the essay shows a remarkable awareness of the limits of the impact Sufi lodges have on Muslim communities and the public sphere in present-day Daghestan, and Shikhaliev's cautious view of the identification of Daghestani Muslims with the Sufi lodges is commendable.

In his contribution on "Islamic Education in post-Soviet Daghestan," Amir Navruz offers a well-structured description of the activities of Islamic institutions of higher education. He concentrates on three of them : the first two - Imam al-Shafi'i Islamic University and Shaykh Muhammad 'Arif North Caucasus Islamic University - are situated in Makhachkala, while the third - Imam al-Ash'ari Islamic University - is located in Khasavyurt. Navruz explains that the curricula of these newly founded institutions of Islamic learning "reflect the priorities of pre-Soviet and Soviet madrasas in Daghestan." With regard to the curricula and the tutoring system they have adopted, Navruz basically holds that they were structured on Soviet educational models. He also argues that the first two levels of Islamic education "remind one of the so-called 'eliminationof-illiteracy' classes of the early Soviet period." With regard to possible continuities with the Soviet past, the essay includes a noteworthy discussion of the teaching staff. He claims that $58 \%$ of the instructors grew up in the late Soviet period. This "spiritual elite", as Navruz calls them, thus, embody the prejudice that "Islamic knowledge and rituals have been preserved in their purest form in Daghestan," and they therefore seem not to be receptive to the educational trends at work in the Middle East, which they perceive as innovations. Navruz's material and the conclusions he draws from the data he gathered are thought-provoking: despite the great prestige acquired by Islamic institutions of higher education, "it is quite unlikely that the Muslim school will be able to supplant its secular state-run competitor in the near future." This, he contends, has to do with two factors: (1) the administrators of institutions of Islamic education seem oriented toward a restructuring of an idealized view of what the pre-Soviet madrasas were like, thus failing to understand that Daghestani society underwent major changes in the Soviet period, the most notable being, as Navruz argues, profound secularization ; (2) graduates of Islamic schools have few opportunities to find employment in Daghestan; their studies can at best qualify them for a position in the muftiate, whose authority, however, is not recognized, especially by young people. 